EESTI NSV TEADUSTE AKADEEMIA TOIMETISED 1955. IV kd., nr. 4

ИЗВЕСТИЯ АКАДЕМИИ НАУК ЭСТОНСКОИ ССР 1955. ТОМ IV, № 4

\title{
PEREMEESTE JA SULASTE OSAST TALURAHVA ANTIFEODAALSE- TES VÄLJAASTUMISTES XIX SAJANDI KESKPAIKU EESTIS
}

\author{
J. КАНК, \\ ajalooteaduste kandidaat
}

Küsimus talurahva erinevate sotsiaalsete rühmituste osatähtsusest XIX sajandi keskel Eestis arenenud antifeodaalses talurahvaliikumises on küllaltki oluline. Selles küsimuses võltsivad eesti kodanluse apologeedid veel praegu jultunult ajalugu. Püüdmatagi oma väiteid tõestada ajalooliste faktidega, väidavad nad, et XIX sajandi keskpaiku kõigi sotsiaalsete liikumiste kandjaks oli „,iseteadlik talupoegkond, eeskätt peremeeste näol”, et kõigis neis liikumistes kajastus kodanlik ,uueaegne, isikliku võitluse vaim" '.

Marksistlikule ajalooteadusele on selline aprioorne apologiseerimine võõras. Peab aga tunnistama, et ka nõukogude ajaloolased pole suutnud vaadeldavat küsimust veel lõplikult lahendada. Pokrovski ebateaduslik seisukoht, et pärast 1861. a. reformi võis revolutsiooniliseks jääda ainult jõukas talupoeg, ning et vaibus revolutsiooniline meeleolu külakehvistu hulgas, on küll juba purustatud ${ }^{2}$. Kuid talurahva erinevate sotsiaalsete rühmituste osatähtsuse hindamisel XVIII ja XIX sajandil toimunud antifeodaalseis talurahvaliikumistes pole siiski veel jõutud ühistele seisukohtadele. Osa nõukogude ajaloolasi on seisukohal, et juba XVIII sajandi lõpus ja XIX sajandi esimesel poolel oli antifeodaalse võitluse peamiseks kandjaks külakehvistu, kuna aga jõukamad talupojad hoidusid reetlikult mõisniku poole ${ }^{3}$. Teine osa ajaloolasi on aga arvamisel, et kuni XIX sajandi $60-70$-ndate aastateni astus talurahvas, nii jõukad kui vaesed talupojad, mõisnike vastu välja ühise rindena ${ }^{4}$.

1 M. O j a m a a, A. ja T. V a r m a s, Eesti ajalugu, Stokholm 1946, lk. 219, 224, 227. E. U us t a lu, The History of Estonian People, London 1952, p. 122.

2 Vt. M. E. M а рков ски й, К истории крестьянских движений на Украине в 70-x годах XIX в., «Исторические записки», № 5 , стр. 235.

3 Н. Л. Р у б и нш те й н, К характеристике вотчинного режима и крестьянского движения в конце 70-x гг. XVIII века, «Исторические записки», № 40, стр. 141.M. Е. М а рков ски й, op. cit., стр. $243-244$. - Ф. С. Горовой, Волнения крестьян Пермского Предуралья в 60-х годах XIX века, Молотов 1951, стр. 150.

4 И. Игнатович, Крестьянские волнения первой четверти XIX века, «Boпросы истории», 1950, № 9, стр. 63. - П. Г. Р ынд 3 юн ски й, Расслоение крестьянства и классовая борьба в крепостной вотчнне в 20-х гг. XIX в., «Исторические запискн», № 4, стр. 164. - Л. Г ен к ин, Помещичьи крестьяне Ярославской и Костромской губернии перед реформой и во-время реформы 1861 г., т. 1, Ярославль 1947, стр. 195-196. - К. В. С и в ков, Очерки по истории крепостного хозяйства и крестьянского движения в России в первой половине XIX века, Москва 1951, стр. 245246. - Viimast seisukohta jagab ka talurahvaliikumist Venemaal 1825-1863. aastail käsitleva uurimuse autor J. I. L i n k ov. (Vt. Я. И. Л и н ков, Очерки истории крестьянского движения в России в 1825-1861 гг., Москва 1952, стр. 139, 188, 258-260.) 
XIX sajandi 40-60-ndad aastad tähistavad Eesti põllumajanduses aeglaselt ja talurahvale piinarikkal nn. preisi tüüpi teel arenenud kapitalismi võidulepääsemist. Feodaalse tootmisviisi ja orjastava teorendisüsteemi kriisist räägivad 1840-1850-ndail aastail selget keelt põlluviljakuse ebaloomulikult aeglane kasv või isegi langus ${ }^{5}$. Hoolimata sellest püüdsid balti parunid kangekaelselt säilitada iganenud teorendisüsteemi, soovimata loobuda sel viisil talupoegade käest röövitavast, sisuliselt tasuta tööst. Balti aadli agraarpoliitika paistab eriti 1850 -ndail aastail silma oma äärmise reaktsioonilisusega. Mõisnikud võitlesid raevukalt kodanliku, talupoegliku väikemaavalduse tekkimise vastu, püüdsid ,päriliku” rendi nime all konserveerida vana pärisorjuslikku teorenti.

Kuid nii kaubatootmise hoogne arenemine, põllumajanduse ratsionaliseerimise möödapääsematus kui ka talurahva klassivõitluse tõus, kus teineteist tugevdavaiks komponentideks olid balti kubermangude ja muu Venemaa talurahva väljaastumised, sundisid balti mõisnikke ja tsaarivalitsust minema järjest uutele järeleandmistele, teostama kodanlikke reforme. 1840-ndail aastail Liivimaal tõusnud talurahvarahutuste ,,järellainetused” polnud rüütelkonna maapäevadel ja valitsuse komisjonides veel vaibunud, kui 1858. aastal mône kuu jooksul tõusis oma mõisnike vastu võitlusse üks viiendik Eestimaa kubermangu talupoegadest ning toimus karistussalga purukslöömine ülestõusnute poolt - kuulsas „Mahtra sõjas”. Samal ajal ei tahtnud ka Liivimaa talurahvas enam edasi virelda feodaalse rõhumise orjuses. Talurahva protest väljendus massilises väljarändamisliikumises, mis 1860-ndate aastate algul haaras ka Eestimaa kubermangu. Mõisnikud ja tsaarivalitsus saatsid selle liikumise mahasurumiseks küladesse pataljonide viisi sõjaväge.

Talurahva antifeodaalse võitluse lahutamatuks osaks oli 1860-ndate aastate esimesel poolel Lõuna-Eestis levinud palvekirjade liikumine. Tuhandete talupoegade naiivne pöördumine kollektiivsete palvekirjadega tsaari poole hirmutas mõisnikke oma nõudmiste demokraatlikkusega ja talurahvaliikumise enneolematu organiseeritusega. See liikumine aga ei suutnud kasvada organiseeritud revolutsiooniliseks võitluseks. Kõik need talurahvarahutused kujutasid endast kas ülevenemaalise revolutsioonilise situatsiooni koostisosa või selle eel- ja järellainetust.

1856. aasta talurahvaseadusega Eestimaa kubermangus ning 1849. ja eriti 1860 . aasta seadusega Liivimaal sunniti balti aadlikke põhimõtteliselt lubama talupoegliku maaomandi tekkimist. 1860-1870-ndail aastail välja antud seadustega piirati feodaalse teorendi kasutamist ning laiendati talupoegade isiklikke öigusi ja vabadusi.

Eesti külas toimus XIX sajandi keskpaiku väga intensiivne sotsiaalse diferentseerumise protsess. Talurahvas hakkas üha suuremal määral lõhestuma külakodanluseks ja maaproletariaadiks. See protsess arenes aga feodaal-pärisorjusliku tootmisviisi surve tingimustes ning hiljem, pärast kapitalistliku tootmisviisi võidulepääsemist, feodaalkorra igandite surve tingimustes. Eesti küla suhtes XIX sajandi keskpaiku on kasutatav Lenini geniaalne iseloomustus vene küla kohta 1905. a. revolutsiooni eel. „Kuivõrd meie külas pärisorjuslik ühiskond tõrjutakse välja „kaasaegse” (kodanliku) ühiskonna poolt, niivõrd talurahvas lakkab olemast klass, jagunedes maaproletariaadiks ja makodanluseks (suureks, keskmiseks, väikseks ja kõige väiksemaks). Kuivõrd säilivad veel pärisorjuslikud suhted, niivôrd „talurahvas” jääb veel püsima klassina, s. o. kordame, mitte kodanliku, vaid pärisorjusliku ühiskonna klassina. See „kuivõrd - niivörd”

5 Eesti NSV ajalugu kolmes köites, peatoimetaja G. Naan. 1 kd., toimetanud A. Vassar, Tallinn 1955 , lk. 615 . 
eksisteerib tegelikkuses äärmiselt keeruka pärisorjuslikkude ja kodanlikkude suhete põimumisena kaasaegses vene külas" ${ }^{6}$.

Eespool loetletud arvukaist klassivõitluse faktidest oli võimalik täpsemalt analüüsida ainult osa. Siinkohal vaatleme selle üleminekuetapi esimesele poolele iseloomulikku 1858. aasta talurahvaliikumist Eestimaal ja selle etapi teisele poolele langevat talurahva palvekirjade esitamist.

1858. aasta kevadel astusid talupojad kogu Eestimaa kubermangus välja nõudmisega viivitamatult kaotada üks teoorjuse vihatumaid vorme - abitegu $^{7}$. Julmade sõjaliste eksekutsioonide rakendamine võimude poolt kutsus esile 2. juunil 1858. aastal ülestõusu puhkemise Mahtras, millest võtsid osa enam kui kümne ümberkaudse mõisa talupojad ja mis lõppes talupoegade ajutise võiduga. Mahtra ülestõus innustas talupoegi uutele väljaastumistele. Juuni lõpust juuli keskpaigani osutasid talurahvaliikumises erilist aktiivsust teosulased - 13 mõisas toimusid sel ajavahemikul kokkupõrked teosulaste ja kubjaste-mõisavalitsejate vahel (üldse toimus sel ajal talurahva vastuhakke 15 mõisas). Juuli teisel poolel oli uus talurahvaliikumise tõus: umbes 10 päeva jooksul esines rahutusi 22 mõisas. Talupojad jätkasid pärisorjusliku teorendi kaotamise nõudmist, nende seas hakkas aga levima ka ärevaid jutte maa jagamisest talupoegadele kroonu poolt. Alles augusti teisel poolel, kohati alles septembri alguses, õnnestus kohalikel võimudel, kes massiliselt kasutasid julmi sõjaväelisi eksekutsioone, talurahvaliikumine maha suruda.

Juba pealiskaudsel tutvumisel 1858. aasta talurahvarahutustega torkab silma, et ka mõisnikevastaste väljaastumiste ajal ei kadunud täiesti hõõrumised talurahva üksikute sotsiaalsete rühmituste vahel. Iseloomulik on juba see, et talupojad suhtusid väga suure umbusuga vallaametnike, - vallatalitajate ja vöörmündrite - tegevusse. Mõnede jõukate peremeeste käitumine nende rahutuste ajal oli otseselt reetlik. Kiideva valla rikkaim peremees Jaksman kasutas ära teiste talupoegade keeldumise teotööst, et valida endale kõige paremad viljakoristustükid ja neil tööd alustada. Samal aastal, kui talupojad Mahtras, Kolgas, Maardus, Roosnas, Penningil ja mujal keeldusid mỗisnikele alistumast isegi pärast sõjaväe karistussalkade kohale ilmumist, kirjutas Albu valla rikas talupoeg, varstine mõisarentnik Tomson, môisnike ülesandel pika seletuskirja, milles ta kirjeldas eesti talupoegade elu üsna roosilistes värvides.

Need talurahva omavahelised hõorumised torkasid silma juba mõnedele kaasaegseilegi. Oks neist (tema nime pole seni õnnestunud selgitada) kirjutas 1858. aasta 20. juulil talurahva vastuhakkudest mõisnikele Hiiumaal järgmist: ,On õige huvitav, et Hiiu saarel talupoegade seas tekkis kaks parteid, milledest üks, mis koosneb peremeestest (Wirte), ei õigusta ülestõusu, kuid et ta on vähemuses võrreldes teisega, mis koosneb töölisteșt (Knechte), siis allub ta viimasele ainult hirmu pärast ja tegutseb koos temaga ${ }^{8 "}$ ".

1858. aasta talurahvaliikumise analüüsimisel on talupoegade vastuhakud jaotatud järgmistesse rühmadesse: 1) talupoegade keeldumine teotööst, 2) vastuhakud mõisaametnikele teotöö ajal, 3) kohalike kohtu- ja politseivõimude korraldustele mittealistumine, 4) kohalike kohtu- ja politseivõimude korraldustele mittealistumine, hoolimata sõjaväeüksuste juuresviibimisest ja 5) ülestõus.

6 V. I. Le n i n, Teosed, 6. kd., Tallinn 1952, 1k. 97.

7 1858. aasta talurahvaliikumist Eestis on ulatuslikumalt käsitletud autori käsikirjalises töös „Крестьянское движение 1858 года в Әстонии („Война в Махтра”)”. Allpool on nimetatud tööst kasutatud materjali lehekülgedelt 229-234, 247-254, 257-259, $340-341,350-351,353-358,361-367,373-398,401-402,423-424$.

8 Eesti NSV Riiklik Ajaloo Keskarhiiv (ENSV RAKA), fond 2054, nimistu 1, aasta 1858, säilitusühik 1993, leht 109. 
Hoolimata vaadeldava talurahvaliikumise kohta säilinud arhiivimaterjali rikkalikkusest, õnnestus vastuhakust osavõtnuid nimeliselt kindlaks teha võrdlemisi harva. Veelgi suuremaid raskusi valmistas täpsemate andmete kogumine nende majandusliku olukorra ja sotsiaalse seisundi kohta. Kohtulike juurdlusmaterjalide ja revisjoninimekirjade põhjal oli võimalik kindlaks teha, kas nad kuulusid sulaste või peremeeste hulka, ja viimasel juhtumil, kui palju sulaseid vastav isik umbkaudselt pidas. Eestimaa Aadlike Krediidikassa poolt koostatud eriliste Landrolle'de põhjal sai mõnikord kindlaks teha, millal vastava talupoja käes rendil olnud talu välja osteti. Nendega aga autori käsutuses olevad andmed piirdusidki, sest midagi, mis ligilähedaseltki meenutaks vene kubermangude semstvo-statistikat, pole sellest perioodist Eesti kohta säilinud.

XIX sajandi esimese poole ja keskpaiga talurahvarahutuste analüüsimisel tuleb silmas pidada eelkõige järgmist asjaolu. Teokoormuste täitmise eest mõisale vastutas rendikoha peremees. Kui talupojad keeldusid teokoormusi täitmast, siis kutsuti mõisa vastust andma peremehed. Juba see asjaolu tingis, et teotööst keeldumise puhul jäi sulaste tegevus teatud määral tagaplaanile.

Feodaal-pärisorjuslikust teotööst keeldumise juhtumid 1858. aastal on kindlaks tehtud Põhja-Eestis 41 mõisa kohta. Täpsemad andmed on olemas 15 mõisa kohta, neist on 11 mõisa kohta säilinud andmeid ainult taluperemeeste väljaastumisest, 4 mõisas aga astusid väga aktiivselt välja ka sulased (Äeskas, Einmanis) või esines peremeeste ja sulaste ühine vastuhakk (Vaimla, Silmsi).

Viie mõisa kohta õnnestus leida üksikasjalisemaid andmeid ühes vastuhakust osavõtjate nimedega. Rava mõisast on teada 12 aktiivsema vastuhakkaja nimed ${ }^{9}$. Neist neli talupoega (Türsama, Pertel, Karrosohn ja Saar) käisid naaberkülas talupoegi vastuhakule üles kutsumas. Kolm mainituist (Türsama, Pertel ja Karrosohn) pidasid talusid, mis osteti mõisa käest päriseks esimestena vallas (1893. a.), kusjuures talupojad maksid nende eest 3200-3800 rubla. Kaheteistkümnest nimeliselt teada olevast aktiivsemast vastuhakkajast pidasid 6 selliseid talusid, mis osteti Raval päriseks esimestena. Olejäänud kuus peremeest pidasid kohti, mis veel 1907. aastal polnud päriseks ostetud ${ }^{10}$.

Umbes samalaadilised andmed on vastuhakkajate koosseisu kohta ka Sellikülast, Einmanist ja Silmsist. Sellikülas pidasid 12-st nimeliselt teadaolevast aktiivsemast vastuhakkajast ${ }^{11}$ kolm selliseid talusid, mis osteti seal päriseks esimestena. Ulejäänud 9 talu kohta ei onnnestunud kindlaks teha, millal nad päriseks osteti ${ }^{12}$. Aktiivsemate vastuhakkajate hulgas oli 2 vaest talupoega, kes sulaseid-teenijaid üldse ei pidanud ${ }^{13}$.

Einmani mốisas toimunud vastuhakust osavōtjaid on nimeliselt teada 29 taluperemeest ${ }^{14}$. Nendest ühe peremehe käes oli rendil talu, mis osteti päriseks esimesena selles vallas (1876. a.), 12 peremehe talud osteti päriseks teises järjekorras (1892. a.), üks talu osteti välja kolmandas (1896. a.) ja 2 viiendas järjekorras (1900. a.) ${ }^{15}$, kuid 13 talu polnud 1907. aastal veel päriseks ostetud.

Silmsis on vastuhakanuist nimeliselt teada vaid neli taluperemeest ${ }^{16}$.

9 ENSV RAKA, f. 905, nim. 1, a. 1858 , sü. 7, 1. 73-75, 121-122.

10 ENSV RAKA, f. 2486 , nim. 1, a. 1864 , sü. 3531 , 1. 41.

"ENSV RAKA, f. 905 , nim. 1, a. 1858 , sü. 7 , 1. 57-59.

12 ENSV RAKA, f. 2486 , nim. 1, a. 1863 , sü. $3531,1.39$.

13 ENSV RAKA, f. 1864 , nim. A 1, a. 1858 , sü. X:239, 1. 308-321.

14 ENSV RAKA, f. 905 , nim. 1, a. 1858 , sü. 7,1 . $68-70$; f. 862 , nim. 1, a. 1858, sü. $6177,1.8,14$.

is ENSV RAKA, f. 2486 , nim. 1, a. 1863, sü. 3531 , 1. 37.

16 ENSV RAKA, f. 29 , sü. $528 / 70 /$ IV, 1. 57-60. 
Aktiivselt ja julgelt esinenud vallavanem Tikva pidas talu, mis osteti päriseks esimesena (1886. a.). Ulejäänud kolm pidasid talusid, mis osteti päriseks 1898. aastal (üldse oli Silmsis 1858. a. 23 talukohta, neist 14 osteti päriseks 1898. aastaks) ${ }^{17}$.

Kurisoo mõisa suhtes õnnestus kindlaks teha, kui palju pidasid vastuhakust aktiivsemalt osavõtnud peremehed sulaseid ja tüdrukuid. Selgub, et vastuhakust võtsid osa ja sooritasid traagilise käigu Tallinna eeskätt need peremehed, kes pidasid sulaseid ${ }^{18}$. Ilmselt püüti neile tähtsaile läbirääkimistele popse ja vaeseid talupoegi mitte kaasa vôtta.

Terve suure vastuhakkude grupi moodustavad 1858. a. suvel ja sügisel need, millest võtsid osa ainult sulased ja mis seisnesid kas teotööl mỗisaametnikele vastuhakkamises, teotöö korra omavolilises muutmises või keeldumises öisest rehepeksust. Sellelaadilisi vastuhakkamisi oli 13 mõisas.

Kohalike kohtu- ja politseivõimude korralduste täitmisest keeldumine esines 9 mõisas. Kolme vastuhaku kohta (Tammikul, Kiideval ja Mäekülas) on teada, et teosulased etendasid neis kõrvuti peremeestega väga aktiivset osa: õhutasid teisi talupoegi vastuhakule ning ajasid mõisapõllule läinud inimesi töölt ära. Kaks vastuhakku (Karinul ja Kuksemal) toimus aga ainult sulaste osavõtul.

Vastuhakust osavõtnud peremeeste suhtes on säilinud täpsemad andmed kolme mõisa kohta. Tammiku mõisas õnnestus kindlaks teha 10 vastuhakust aktiivsemalt osavõtnud peremeeste nimed ${ }^{19}$. Neist üks pidas sellist talu, mis osteti päriseks esimesena vallas (1896. a.), ja neljal olid talud, mis osteti päriseks teises järjekorras (1900. a.). Viie talu kohta pole aga andmeid, et neid oleks suudetud enne 1907 . aastat päriseks osta ${ }^{20}$. Kiideva ja Mäemốisa kohta õnnestus kindlaks teha ainult seda, et ka siin kuulusid aktiivsemate vastuhakkajate hulka mõned peremehed, kelle talud olid aastaiks 1900 - 1903 juba päriseks ostetud ${ }^{21}$. Enamik aktiivsemate vastuhakkajate käes rendil olnud taludest polnud aga sel ajal veel päriseks ostetud.

Vastuhakk võimudele, hoolimata sõjaväe karistussalga kohalviibimisest, toimus seitsmes mõisas. Neist kahes mõisas (Roosnal ja Putkastes) moodustasid vastuhaku kandva jõu sulased. Vastuhakust osavõtnud taluperemeeste kohta oli täpsemaid andmeid võimalik saada viie mõisa suhtes. Ojasuult on nimeliselt teada 20 vastuhakust osavõtnud peremeest ${ }^{22}$. Neist 7 pidasid talusid, mis osteti päriseks esimestena (juba 1866. a.), ja kaks selliseid talusid, mis teises-kolmandas järjekorras (1869. ja 1884. a.) päriseks osteti. Ulejäänud 11 peremehe rendikohad polnud 1907. aastal veel päriseks

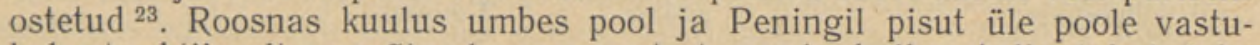
hakust aktiivselt osavõtnud peremeestest nende hulka, kelle talud juba 1890 -ndate aastate alguseks päriseks osteti ${ }^{24}$. Putkaste ja Kolga mõisa kohta õnnestus kindlaks teha ainult seda, et seal kuulus aktiivsemate vastuhakust osavõtjate hulka nii neid peremehi, kes pidasid sulaseid ja tüdrukuid, kui ka neid, kel palgalisi polnud ${ }^{25}$.

17 ENSV RAKA, f. 2486, nim. 1, a. 1863, sü. $3531,1.76$.

18 ENSV RAKA, f. 905, nim. 1, a. 1858, sü. 7, 1. 57, $62-63,71-73$; f. 29, sü. 523/70,

1. $328-329$; f. 1864 , nim. A 1, a. 1864 , sü. X:234, 1. $140-156$.

19 ENSV RAKA, f. 861 , nim. 1, a. 1858 , sü. $1778,1.12-22,30-31$.

20 ENSV RAKA, f. 2486, nim. 1, a. 1864 , sü. $3530,1.69$.

21 ENSV RAKA, f. 29, a. 1858 , sü. $525 / 70$ II, 1. $207-213$; f. 2486 , nim. 1, a. 1863 , sü. $3532,1.97$ ja $104-105$.

22 ENSV RAKA, f. 29, a. 1858 , sü. $523 / 70,1.37-38$.

23 ENSV RAKA, f. 2486, nim. 1, a. 1864 , sü. $3530,1.59$.

24 ENSV RAKA, f. 905, nim. 1, a. 1858 , sü. $7,1.64-67$; f. 29 , a. 1858 , sü. $525 / 70$ II, 1. $136-139$; f. 2486 , nim. 1, a. 1864 , sü. $3530,1.24$; sü. $3531,1.6-7$.

25 ENSV RAKA, f. 29, a. 1858 , sü. $528 / 70$ IV, 1. $136-141$; sü. $525 / 70$ II, 1. 195-197; f. 1864 , nim. A 1 , a. 1858 , sü. $X: 100,1.1-179$; sü. $X: 333,1.128-173$. 
Mahtras toimunud ülestõusu puhul vangistasid võimud 66 inimest. Nende hulgas oli 30 taluperemeest, 3 peremehe poega, 30 sulast, 2 kõrtsmikku ja 1 alaealine ${ }^{26}$. Olestõusu käigus said haavata või surma 10 taluperemeest, 10 sulast ja 3 popsi ${ }^{27}$. Siinjuures tuleb aga märkida, et grupp Mahtra kõige jõukamaid peremehi käitus avaliku ülestõusu puhkemise hetkel reetlikult, manitsedes ülestõusnuid ,rahunema” ja asudes isegi talupoegade poolt vihatud mõisaopmanit kaitsma.

Mahtras oli 1858. aastal 21 talukohta. 1884. aastaks oli päriseksostu alustatud viies talus, 1889. aastaks kasvas see arv 10-ni ja 1906. aastaks 17-ni. Uks Mahtra ülestõusust osavõtjaid pidas rendikohta, mis osteti päriseks 1884. aastal (see koht osteti 2600 rubla eest); üks pidas kohta, mis osteti päriseks 1889. aastal (hind 1700 rbl.), ja kaks pidasid rendikohti, mis osteti päriseks 1906. aastal (hind 2750 ja 3700 rubla) ${ }^{28}$. Maidla mõisas 1858. aastal olnud 52-st talust oli 1883 . aastal päriseks ostetud 17,1884 . aastal osteti veel lisaks 15 talu. Mahtra ülestõusust osavõtjaist pidasid vallatalitaja Piiper ja peremees Kroon 1858. aastal talusid, mis päriseks osteti 1884. aastaks ${ }^{29}$.

Teoorjusest (konkreetselt abiteost) keeldumise puhul astusid aktiivsemalt välja peremehed, sest just nemad kandsid mõisa ees teo täitmise eest vastutust. Mõisapõllul hakkasid kupjaile ja kiltreile vastu sulased, kes põllul töötasid. Konkreetses ajaloolises tegelikkuses need vastuhakud aga tugevdasid teineteist - toimus 11 eeskätt taluperemeeste väljaastumist, mida toetasid 13 sulaste vastuhakku, kuna neljas mõisas astusid peremehed ja sulased välja ühiselt.

Vastuhaku tugevamate vormide puhul aga, nagu nägime, oli peremeeste ja sulaste osatähtsus peaaegu võrdne.

Peremeeste ja sulaste osatähtsus tugevamates vastuhakkudes

\begin{tabular}{l|c|c|c}
\hline Väljaastujad & $\begin{array}{c}\text { Aktiivselt astu- } \\
\text { sid vălja ees- } \\
\text { kătt talupere- } \\
\text { mehed }\end{array}$ & $\begin{array}{c}\text { Aktiivselt astu- } \\
\text { sid vălja ees- } \\
\text { kătt sulased } \\
\text { iseloom }\end{array}$ & $\begin{array}{c}\text { - Peremehed ja } \\
\text { sulased astusid } \\
\text { valja ühiselt }\end{array}$ \\
\hline $\begin{array}{l}\text { Vastuhakk võimudele } \\
\begin{array}{l}\text { Vastuhakk võimudele } \\
\text { hoolimata sõjavăe juures- } \\
\text { viibimisest }\end{array}\end{array}$ & 4 mõisas & 2 mõisas & 3 mōisas \\
\end{tabular}

Veelgi selgemini kajastus see aga Mahtras toimunud ülestõusust osavõtjate koosseisus.

Paljude vastuhakkudest osavõtjate kohta on eespool märgitud, et nad ostsid oma talud päriseks esimeste hulgas. Eespool osutatud allikaist õnnestus täpsemaid andmeid saada 86 sellise taluperemehe kohta. Nende käes olnud talud jagunesid oma suuruselt (päriseksostetud koha pindala järgi) järgmistesse gruppidesse:

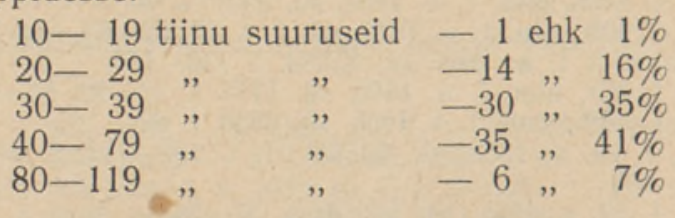

26 ENSV RAKA, f. 29 , a. 1858 , sü. 70 V-a 529, 1. 59-61.

27 ENSV RAKA, f. 29, a. 1858 , sü. 525/70 II, 1. 288-290.

28 ENSV RAKA, f. 2486, nim. 1, a. 1864, sü. 3530. 1. 50.

29 ENSV RAKA, f. 1864 , nim. A 1, a. 1858 , sü. X:123, I. $330-353$; f. 2486 , nim. I, a. 1864 , sü. 3530 , 1. 51 . 
Nimetatud 86 talu keskmine hind ületas 1,4 korda talu keskmise hinna kubermangus sel ajal ${ }^{30}$.

Nagu toodud andmeist näeme, pidas rõhuv enamik vaatluse alla võetud taluperemeestest selliseid kohti, mida oli võimatu harida ainult oma perekonna tööjõuga. Selle tōttu võime neid esimesi talude päriseksostjaid üldreeglina pidada tekkiva külakodanluse esindajaiks.

Seega saame 1858. a. talurahvarahutuste analüüsi põhjal teha kaks järeldust. Esiteks: 1858. a. talurahvaliikumine polnud mingi taluperemeeste vastuhakk, sest sama aktiivselt kui peremehed astusid sel aastal mõisnike vastu välja ka teosulased. Teiseks: jõukamad talupojad, tulevased talude päriseksostjad ei hoidunud veel võitlusest kõrvale, vaid astusid mõisnike vastu välja koos vaeste talupoegadega.

Oma ajalooliselt sisult ja tähenduselt on 1858. aasta rahutustest teatud määral erinev talurahvaliikumine 1860-ndate aastate esimesel poolel LõunaEestis - nn. palvekirjade aktsioon. 1858. aastal astusid talupojad Eestimaal välja môisnike vastu, kes veel kangekaelselt kaitsesid feodaal-pärisorjuslikku tootmisviisi, teoorjust. 1860-ndate aastate esimesel poolel astusid nad Liivimaal välja mõisnike vastu, kes olid juba otsustanud üle minna kapitalistlikule tootmisele. Talupojad astusid välja selle ülemineku mõisniklik-pärisorjusliku, talurahvale äärmiselt laostava ja piinarikka vormi vastu. Nende väljaastumiste julm mahasurumine võimaldas balti mõisnikel kandija moonakülade, töörendi ja muude selletaoliste institutsioonide abil kultiveerida pärisorjuse igandeid põllumajanduses ja külas kuni XX sajandi alguseni.

Veel aastail 1863-1864 oli môisnike endi statistika andmeil valitsevaks. rendivormiks pärisorjuslik teorent.

Lõuna-Eestis oli aastail 1863-1864 taludest

\begin{tabular}{|c|c|}
\hline $\begin{array}{l}\text { aturaalrendil (segarendil) } \\
1 \text { de poolt välia ostetud }\end{array}$ & $\begin{array}{l}39,72 \% \\
27,09 \% \\
29,63 \% \\
3,56 \%\end{array}$ \\
\hline
\end{tabular}

Pōhja-Eestis oli teorendi osatähtsus sel ajal veelgi suurem.

Talumaade müük sõltus täiesti mõisnike suvast; maid müüdi talupoegadele röövellike hindadega. Põhja-Eesti 29 mõisa kohta tehtud arvutused näitavad, et nende valdajad pressisid kuni 1906. aastani talupoegadelt müügihinna näol välja 2.421.168 rubla. Mõisnike endi krediidikassa takseerimiskomisjon hindas aga müüdud maade väärtuseks ainult 1.294 .619 rubla ${ }^{32}$. Seega maksid talupojad oma maade eest 1,8 korda rohkem kui oli maade tegelik väärtus mõisnike endi hinnangu järgi.

Selliste hindade juures edenes talumaade müük loomulikult väga visalt. 1900. aastaks oli Pōhja-Eestis müüdud vaid $52 \%$ talumaast ${ }^{33}$, kusjuures suurel osal müüdud maast lasus rõhuv krediidikassa võlg.

Eespool oli juttu, et 1858. aasta rahutustest Põhja-Eestis võtsid osa ka peremehed, kelle talud osteti päriseks esimestena vallas. Kuid ka need peremehed suutsid enamikus alustada päriseksostu alles 1880—90-ndail aastail,

so Vt. E. v. Bodisco, Der Bauerland-Verkauf in Estland und Materialien zur Agrar-Statistik Estlands, Reval 1902, S.. 59.

31 A. To bi en, Die Agrargesetzgebung Livlands im 19. Jahrhundert, Bd. II, Riga, 1911 , S. 275.

32 ENSV RAKA, f. 2486 , nim. 1, a. 1864 , sü. $3530,1.2-3,24,28,50-51,57-59$, $67-69,129$; sü. $3531,1.6-7,11,26-27,29,31,38-39,43,76$; sü. $3532,1.97,104$, 138 - 140; sü. $3533,1.21,34$.

33 E. v. Bodis c o, Der Bauerland-Verkauf in Estland und Materialien zur AgrarStatistik Estlands, Reval, 1902, Graphische Darstellung der Entwicklung des Bauerlandverkaufs. 
seega atles $20-30$ aasta pärast, millal nad võisid olla juba $50-60$ aastat vanad või rohkemgi. 1900-ndail aastail oli Põhja-Eestis päriseksostu alustatud alles pisut enam kui pooltes taludes. Järelikult pooled neist peremeestest Põhja-Eestis, kes 1850 - 60-ndate aastate talurahva väljaastumiste ajal olid 30-40-aastased, surid enne kui nad jõudsid päriseksostu alustadagi. Kõige selle tõttu pole imestada, et rõhuv enamik talupoegi vaatas

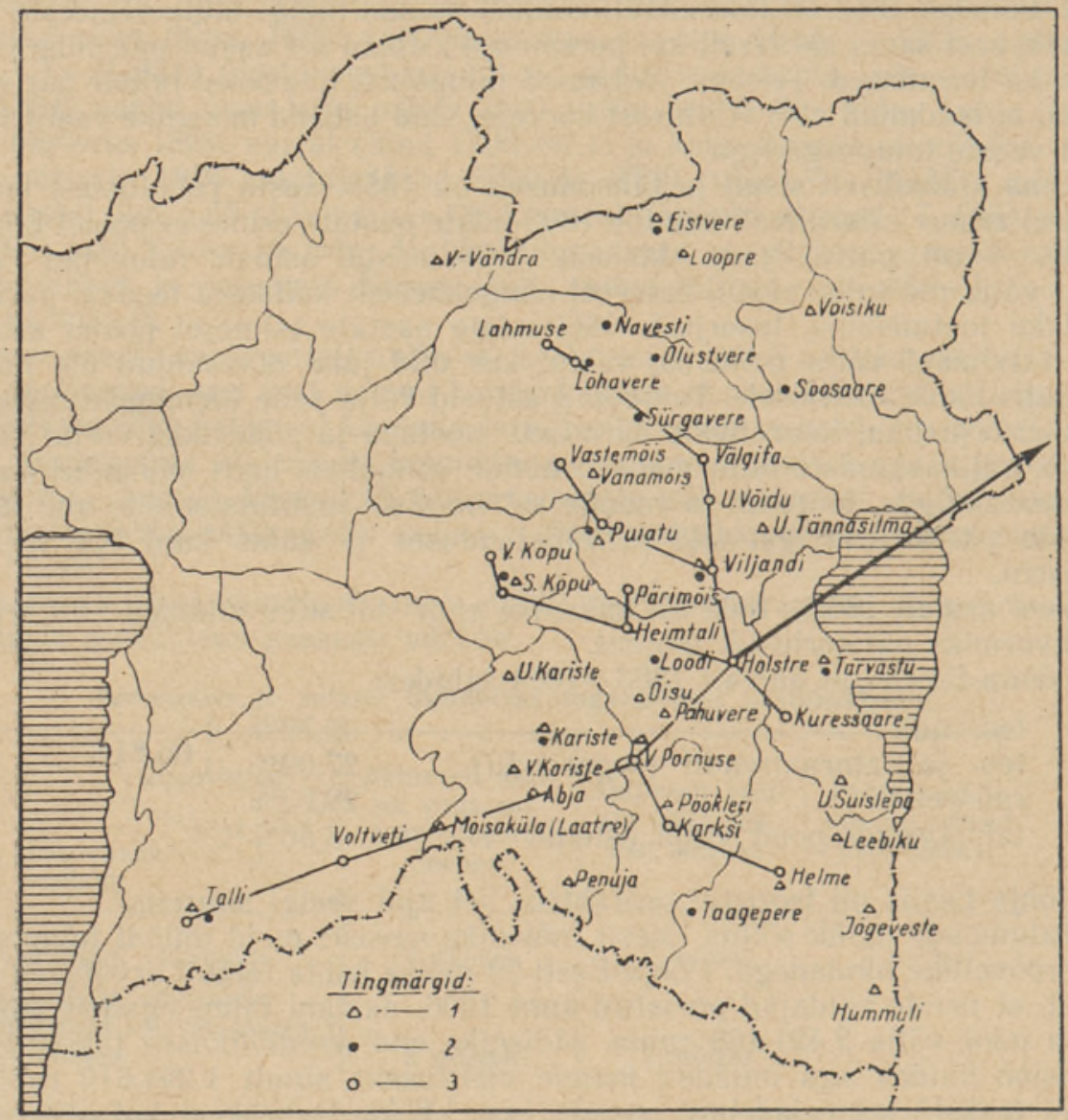

Joon. 1. Talude päriseksostu ja palvekirjade aktsiooni levik Pärnu-Viljandi kreiskohtu piirkonnas.

Märkide seletus: 1 - Mõisad, kus müüdi talusid päriseks enne 1869. aastat. 2 - Mõisad, kust talupojad aastail 1860-1868 saatsid palvekirju tsaarile. 3 - Mốisad, kust talupojad võtsid osa 1864. aasta suurpalvekirjast.

1860-ndail aastail mõisnike poolt neile pealesurutud röövellikule päriseksostule kui suurimale õnnetusele, eriti kui mõisnikud neid seda sundisid tegema kiires korras (sundmüük).

Juuresolev kaart (joon. 1) näitab Pärnu-Viljandi kreiskohtu andmeil ${ }^{34}$, kus mõisates toimus enne 1869. aastat talude päriseks ostmisi. Uhtlasi on

34 ENSV RAKA, f. 919, nim. 1, sü. $3374-3376,3378,3380,3381,3383,3384$, $3386-3388,3393,3394,3396-3407,3409-3415,3417-3420,3422-3423,3425-3427$, $3429-3439,3441-3444,3446,3448,3449-3452,3454,3456,3459,3461,3569$. 
kaardil märgitud, kust mõisatest talupojad saatsid aastail 1860-1868 palvekirju tsaarile ${ }^{35}$.

Nagu näeme, algas nn. palvekirjade aktsioon just seal rajoonis, kus mõisnikud esimestena alustasid talude müüki. Sellest räägivad kujukalt ka talupoegade palvekirjad, kus pidevalt kaevatakse röövelliku sundmüügi üle.

Kuid oleks väär neid kaht protsessi kunstlikult sidudes pidada palvekirjade aktsiooni mingiks ainult tõusva külakodanluse liikumiseks, mille juures lihtsalt kaubeldi mõisnikega müügihindade suuruse pärast. Juba juuresolevalt kaardilt võime välja lugeda järgmist: 27 mõisas koostati teadaolevail andmeil kuni 1868. aastani talupoegade poolt kollektiivpalvekirju, kuid neist polnud 18 mõisas talude müümist sel ajal veel üldse alustatud.

Paljud talupoegade palvekirjad olid otseselt suunatud mõisnike poolt praktiseeritava röövelliku sundmüügi vastu. Neid kandis mitte niivõrd talupoegade soov oma talusid päriseks osta, kuivõrd hirm neist hoopis ilma jääda. „Minna waene Eestimaa tallo poeg, tullen suure allandlikko ja häddalikko palwega Teie juure suur armolik Keiser, et minno omma issa majast wälja aeti, ja minno ollin seäl kolmas põlw rahwast ellamas..." ${ }^{36}$, selliste sõnadega pöördus tsaari poole 1864. aastal üks Tarvastu talupoeg. Maa sundmüügi vastu protesteerisid 1864. aastal Suure-Kõpu talupojad, 1865. aastal Puiatu ja Karula talupojad ${ }^{37}$. Loodi talupojad nõudsid 1865. aastal talude müügi keelamist, kuni „kroonu hinnad määrab” ${ }^{38}$. Sundmüügi vastu oli suunatud ka 1864. aastal koostatud 23 talurahvakogukonna kollektiivne palvekiri.

Selle kõrval nõudsid talupojad feodaal-pärisorjusliku teorendi kaotamist. „Paljo tallud orjawad meie keigesuremaks kahjuks weel täieliko teo orjust; muist on tema (mõisnik - $J$. K.) kül ka kõrge seggase rendi peale annud, mis meil nisama ehk weel raskem on kui täielik teo-orjus ..." ${ }^{39}$, kirjutasid 1864. aastal Karula talupojad. Navesti peremehed kurtsid 1865. aastal, et mõisnik keeldus neilt renti rahas vastu võtmast ${ }^{40}$.

Kuni 1865 . aastani koostati palvekirju kõigi vastavasse kogukonda kuuluvate talupoegade poolt ühiselt. Et pareerida võimude süüdistusi - palvekirjad kajastavat vaid taluperemeeste huve, - koostati 1866. aastal palvekirjad eraldi peremeeste ja sulaste poolt. Aastail 1867-1868 koostati palvekirjad uuesti tervete kogukondade nimel.

Siinjuures võib tekkida kahtlus, kas ei kajasta palvekirjad isegi sel juhtumil, kui nad kannavad sulaste allkirju, siiski peremeeste huve? Kas peremehed lihtsalt ei sundinud majanduslikult neist sõltuvaid sulaseid peremeeste huve kajastavaile palvekirjadele alla kirjutama?

Vastuse neile küsimustele annab kõigepealt mõnede palvekirjade analüüs, kuid ka 1860-ndate aastate keskpaiku Holstre kogukonnas aset leidnud sündmused.

Loodi ja Karula mõisas esitati 1865. aastal palvekirjad eraldi sulaste ja peremeeste poolt ${ }^{41}$. Peremehed ja sulased arvestasid siinjuures hoolikalt teineteise huve. Kõigis neis palvekirjades nõuti mõisniku poolt taluperemeeste käest röövitud ja mõisa külge liidetud talumaade tagasiandmist. Peremehed ei nõudnud neid maid aga tagasi endale, vaid oma palvekirja-

36 Hans Kr u us, Eesti rahvusliku ärkamise algupäevilt, „Eesti Kirjandus”, 1934, a., lk. $339-340,344,345,456,459-461,466$. - ENSV RAKA, f. "915, nim. 1, III k., a. 1856, sü. $4006 / 159,1.90-97$.

36 ENSV RAKA, f. 915, nim. 1, III k., a. 1865 , sü. 4006/159, 1. 62.

37 ENSV RAKA, f. 932 , nim. 1, a. 1864 , sü. $394,1.6 ;$ f. 296 , a. 1866 , sü. $177,1.57,83$.

3 ENSV RAKA, f. 915 , nim. 1, III k., a. 1865, sü. $4006 / 159$, I. $90-91$; f. 296, a. 1866 , sü. $177,1.41$.

39 ENSV RAKA, f. 915, nim. 1, III k., a. 1865, sü. 4006/159, 1. 70.

to ENSV RAKA, f. 296, a. 1866, sü. 177, 1. 93.

4) ENSV RAKA, f. 296 , a. 1866 , sü. 177,1 . $26-27,40-44,78-88$. 
des otseselt rõhutasid, et tagasiantud maad tuleb ,,sobiva” rendi või müügihinna eest jagada sulastele ja teistele maatutele. Sama nôuet kordasid oma palvekirjades loomulikult ka sulased, kuid vastutasuks kinnitasid nad oma palvekirjades, et taluperemehi mõisniku poolt väga julmalt rōhutakse ja et maade müügihinnad on väga kõrged. Maa jagamist mõisamaade arvel nõudsid ka Puiatu ja Vana-Kõpu sulased ning Sürgavere ja Vana-Kõpu popsid ${ }^{42}$. „Meie suur ma pudus on üksnes meie pärrisherra sure kasso nōudmisse läbbi tulnud" ${ }^{43}$, nii sõnastasid 1865. aastal Loodi sulased Liivimaa eesti osa teosulaste ja maata talupoegade üldise veendumuse.

Palvekirjade sisust ei saa kuidagi teha järeldust, et nad oleksid sulastele peremeeste poolt peale surutud ja et sulased oleksid nende nõudmiste formuleerimisel olnud kahjukannatavaks pooleks. Mõisnike võimu kukutamine, mõisate likvideerimine oleks kergendanud nii taluperemeeste kui ka sulaste olukorda. Seda tõsiasja kajastavad ka 1860-ndate aastate palvekirjad.

Veel kujukamalt kinnitavad sedasama aga sündmused Holstres, 1860-ndate aastate palvekirjade aktsiooni ühes tähtsaimas keskuses.

Palvekirjade aktsioonis etendasid juhtivat osa vennad Petersonid, kes 1860-ndate aastate esimesel poolel elasid Holstres ${ }^{44}$. Nende abiga kirjutati suur osa talupoegade palvekirjadest ning nemad juhtisid tähtsamaid talupoegade saatkondi, kes käisid Peterburis. Kõige selle tõttu kiusati vendi Petersone mõisnike ja sandarmite poolt julmalt taga, Adam Petersoni tervis murti vanglais ning Peeter Peterson saadeti asumisele.

Palvekirjade aktsioonist võtsid Holstre talupojad osa väga aktiivselt ja meelekindlalt. 1864. aastal majutati Holstresse talupoegade karistamiseks kasakad. Kõik Holstre kogukonna ametnikud kui palvekirjade aktsioonisse segatud isikud tagandati kohalike võimude poolt. Hoolimata neist repressioonidest keeldusid talupojad kahel avalikul kogukonna koosolekul (1866. a. jaanuaris ja juunis) tunnustamast oma kogukonna ametnike tagandamist ega valinud uusi ametnikke ${ }^{45}$. Tartu sandarmiosakonna ülem polkovnik Andrejanov kirjutas 1866. a. oktoobris, et Holstre talupojad olevat muutunud ,täiesti vabariiklasteks” ${ }^{46}$.

Samal ajal toimus Holstres aga veel teisi ning mitte vähem olulise tähtsusega sündmusi. Holstre oli riigimõis. 1866. a. märtsis õnnestus kohalikul talurahvakogukonnal võtta mõis enda kätte rendile ${ }^{47}$. See rendile võtmine oli aga ainult hoopis ulatuslikuma programmi elluviimise alguseks. Talupojad valisid endi hulgast mõisa valitsuse, mis pidi tegutsema ainult kuni mốisa „ärajagamiseni ${ }^{48}$ ". Mõisa ärajagamine tähendas aga eeskätt maata talupoegade, sulaste ja popside varustamist maatükkidega seni mõisa otseses valduses olnud maade arvel. Talupojad pöördusid juba 1865 . aastast alates vastavate taotlustega Riigimõisate Ministeeriumi, ja kui nende palveid ei rahuldatud, jagas uus talupoegadest koosnev mõisavalitsus ise osa mõisamaast 45 maata talupoja vahel ära ${ }^{49}$.

Kõige ülaltoodu põhjal ei saa olla kahtlust, et talupoegade poolt 1866. aastal valitud mõisavalitsus esindas õige suurel määral Holstre maatarahva, sulaste ja popside huve. Uhtlasi on aga selgesti näha; et sulaste ja

42 ENSV RAKA, f. 296 , a. 1866 , sü. 177 , 1. 65 , 105; f. 932 , nim. 1, a. 1868 , sü. 395 , 1. $2-3$.

43 ENSV RAKA, f. 296, a. 1866 , sü. $177,1.26$.

44 Vendade Petersonide tegevusest vt. lähemalt $\mathrm{H}$. Kru us, op. cit. - J. Kah k „Uusi andmeid eesti rahvusliku liikumise demokraatliku suuna ajaloost”, „Rahva Hääl”, 8. jaanuar 1955. a.

45 ENSV RAKA, f. 3671 , nim. 1, a. 1865 , sü. 8, 1. $27-34,91$.

46 Riiklik Ajaloo Keskarhiiv Moskvas (RAKA M.), f. III osak., IV eksp., a. 1866, sü. $139,1.17$.

47 ENSV RAKA, f. 3671, nim. 1, a. 1865 , sü. 8, 1. 49-50.

18 Samas.

49 ENSV RAKA, f. 3671 , nim. 1, a. 1865 , sü. 10, 1. 163-165. 
muu maata rahva olukorra parandamist püüti saavutada mõisalatifundiumide arvel. See on aga iseloomulik kogu 1860-ndate aastate palvekirjade aktsioonile.

Holstre maatarahva huvide kaitsjaks Riigivarade Ministeeriumis, 1866. aastal valitud mõisavalitsuse tähtsaimaks liikmeks ja lõpuks 45-le sulasele ja popsile maatükkide jagamise teostajaks oli Adam Peterson, kogu palvekirjade aktsiooni tunnustatud ja autoriteetne juht ${ }^{50}$. 1866 . aasta kevadel valiti Adam Peterson Holstre mõisavalitsuse koosseisu eeskätt sulaste häältega ${ }^{51}$.

Sulaste erilisest aktiivsusest räägib ka sandarmiosakonna ülem polkovnik Andrejanov oma ettekandes 1866. aasta 17. oktoobrist: „V V i m a s e l a j a 1 kogunesid Viljandi läheduses mingile nõupidamisele sulas ed (Knechte), kuid nende kogunemise e esmärk, samuti ka aeg jäi võimudele saladuseks, nad kuulevad neist juba pärast nende toimumist, kuulujuttude kaudu ${ }^{52}$ ',.

Kõik eespooltoodu peaks veenvalt rääkima sellest, et ka 1860 -ndate aastate palvekirjade aktsioonist võtsid sulased küllaltki aktiivselt osa, et nad otsisid sel ajal oma raskest olukorrast väljapääsu mitte taluperemeeste ja tekkiva külakodanluse, vaid mõisnike arvel.

Palvekirjade aktsioonist osavõtnute nimekirjade analüüs näitab, et neist ei hoidunud kõrvale ka tekkiv külakodanlus. Suure-Kõpu talupoegade palvekirjale 1. juulist 1864, milles protesteeriti eeskätt maade sundmüügi vastu röövellikult kõrgete hindadega, kirjutas alla 77 talupoega ${ }^{53}$. Kuid juba 22 päeva pärast sõlmis üks neist mõisnikuga ostulepingu; kahe aasta jooksul järgnesid tema eeskujule veel 6 allakirjutanut ja 1868. aastaks tõusis nende arv kaheteistkümneni ${ }^{54}$. Heimtali talupoegade palvekirjale 1864 . aastast on alla kirjutanud 36 . inimest ${ }^{55}$, kelle seast neli peremeest sõlmis juba 1875. aastal mõ̃isaga ostulepingu ${ }^{56}$. Puiatu talupoegade 1865 . aasta palvekirjale allakirjutanud 21 talupoja hulgas ${ }^{57}$ on üks peremees, kes juba kahe aasta pärast asus oma talu päriseksostmisele; paljud talud näivad aga juba 1880-ndail aastail olevat päriseks ostetud allakirjutanute poegade poolt ${ }^{58}$. 1864. aasta suurmärgukirjale on Holstre kogukonna nimel alla kirjutanute seas kaks taluperemeest, kellest on teada, et nad tegelesid laenude andmisega teistele talupoegadele ${ }^{59}$.

Tekkiva külakodanluse suhtumisest 60-ndate aastate ühiskondlik-poliitilistesse liikumistesse Eestis räägivad ka L. Loone ja O. Sepre oma artiklis „Majanduslik mõte Eestis XIX sajandil”. Kahjuks on see käsitlus aga pisut lihtsustatud. Artiklis räägitakse, et ka tekkiv külakodanlus suhtus vaenulikult feodaalsuhete valitsemisse, sest põllumajandussaaduste ,.... ülesostmine ja edasimüümine oli äärmiselt piiratud, talumaade rentimine oli peaaegu võimatu, veskid ja kõrtsid kuulusid mõisnikele” ${ }^{60}$. Samas tullakse aga järeldusele, et kogu tekkiv külakodanlus otsis kompromissi mõisnikega.

50 On iseloomulik, et just samadel aastatel soovitas ka C. R. Jakobson Holstre talupoegadele, et sulased esitaks ministeeriumi palvekirju riigimöisate jaotamiseks maata talupoegadele (C. R. Jakobsoni kiri Jaan Adamsonile, jaanuar 1869. a.).

31 ENSV RAKA, f. 3671, nim. 1, a. 1865 , sü. 8, 1. 125.

52 RAKA M., f. III osak., IV eksp., a. 1866, sü. 139, 1. 17.

53 ENSV RAKA, f. 932, nim. 1, a. 1864, sü. 394, 1. 8-10.

54 ENSV RAKA, i. 2469 , nim. 1, sü. $4528,4532,4538,4542,4543,4546,4553-4555$, $4558,4562-4564$

55 ENSV RAKA, i. 915, nim. 1, III k., a. 1865, sü. 4006/159, 1. 77.

56 ENSV RAKA, f. 2469, nim. 1, sü. 5788, 5794-5796, 5802.

57 ENSV RAKA, f. 296, a. 1866, sü. $177,1.61$.

58 ENSV RAKA, f. 2469, nim. 1, sü. 4581, 4578-4580, 4584, 4586.

59 ENSV RAKA, f. 915, nim. 1, III k., a. 1865, sü. 4006/159, 1. 95; f. 3671, nim. 1, sü. $11,1.18,41$; sü. $12,1.87-88,116,134$; sü. 13, i. $38,53$.

60 „Eesti Kommunist”, 1955, nr. 5, 1k. 67. 
Eelmises artiklis ${ }^{61}$ vaatlesime külakodanluse rühma, mis hakkas tekkima juba XVIII sajandi lõpus ning XIX sajandi alguses ja rekruteerus kupjaist, möldreist, kõrtsmikest ja teistest mõisnike käsikutest. Neile olid eespool nimetatud kitsendused just soodsad. Raskused põllumajandussaaduste ja maade ostmisel piirasid nende võistlejate ringi. Veskite ja kõrtside kuulumine mõisnikele nende tegevust eriti ei takistanud, sest talupoegadelt väljapigistatud kasudega võrreldes oli mõisarent tavaliselt küllalt väike. Selline olukord tugevdas aga neile eluliselt tähtsat sidet mõisnikega. On loomulik, et see kiht külakodanlusest oli huvitatud mõisnike ja talupoegade huvide „,kooskõlastamisest”.

Alates 1840-50-ndaist aastaist taluperemeeste kõige laiemaist hulkadest väljakasvava külakodanluse olukord oli aga, nagu nägime, hoopis teine. Külakodanlus oli huvitatud liitlase omamisest võitluses mõisnikega ja seetõttu ka oma huvide teatavast kooskõlastamisest sulaste huvidega. XX sajandi alguses oli see osa külakodanlusest, radikaalne väikekodanlus, võimeline demokraatlikuks võitluseks proletariaadi juhtimisel, kuna ta „vanem vend" - suur- ja linnakodanlus reetis ta huvid mõisnikele ja tsarismile.

Kõige ülaltoodu pōhjal jõuame 1860 -ndate aastate palvekirjade aktsiooni suhtes samale järeldusele kui 1858 . aasta talurahvarahutuste kohta. Sellest võtavad ühesuguse aktiivsusega osa nii talurentnikud kui ka maata inimesed - sulased ja popsid. Pole mingit alust väita, et seda võitlust kannaks või juhiks tekkiv külakodanlus. Samal ajal aga näeme, et tärkava külakodanluse laiemad ringid ei hoidu sellest võitlusest eemale. Võitluse teravik on suunatud mõisnike, mõisalatifundiumide vastu.

1840-ndate aastate talurahvaliikumise analüüsi põhjal jõudis Hans Kruus omal ajal järeldusele, et sellest võtsid osa kõik talurahva sotsiaalsed rühmitused ${ }^{62}$. Samasuguste tulemusteni jõudis ka L. Loone (L. Rebane) 1880-ndail - aastail Loode-Eestis talurahva hulgas levinud usuvahetusliikumise kohta ${ }^{63}$.

V. I. Leninit huvitas küsimus talurahva üksikute sotsiaalsete rühmituste osavõtust antifeodaalsest liikumisest kui revolutsioonilise praktika ja marksistliku teooria tähtis küsimus. Selle küsimuse lahendamisel toetus ta 1905. aasta revolutsiooni kogemustele; ta luges selle probleemi uurimisel Marxi tööd „Kodusõda Prantsusmaal” ning Marxi ja Engelsi artikleid „Neue Rheinische Zeitung'is" ${ }^{64}$. Teatavasti olid vene sotsiaaldemokraadid esialgu seisukohal, et ,vaevalt saab kogu talurahvas solidaarselt minna kaugemale nõudmisest tagastada äralōigatud maad, sest et paratamatult tuleb teispool sellise agraarümberkujunduse piire selgelt esile maaproletariaadi ja „heade peremeeste" antagonism" ${ }^{65}$. Kuid revolutsiooni kogemused näitasid, et 1905.-1907. a. revolutsiooni ajal astus talurahvas veel lõpuni välja ühtse klassina ${ }^{66}$. Vastavalt sellele töötasid bolševikud ümber oma programmi ja rõhutasid oma agitatsioonitöös, et mõisnike vastu peab kehvtalurahvas minema koos kogu talurahvaga, sealhulgas ka tekkiva külakodanlusega ${ }^{67}$. Lenin tõestas geniaalselt, et võitlusest mõisnikega, mõisalatifundiumide jagamisest on huvitatud ka külakodanlus.

61 J. K a h k, Külakodanluse ja maaproletariaadi tekkimisest Eesti külas, Eesti NSV Teaduste Akadeemia Toimetised, 1955, nr. 3.

62 Hans- Kruus, Talurahvakäärimine Lōuna-Eestis XIX sajandi 40-ndail aastail, Tartu 1930, lk. 397-398.

63 L. R e b a n e, Usuvahetuslik liikumine Läänemaal aa. 1883-1885, „Ajalooline ajakiri", 1933, lk. 135-136.

64 V. I. L e n i n, Teosed, 13. kd., Tallinn 1953, lk. 193. - 9. kd., Tallinn 1952, lk. 90, $103,106-112$

65 V. I. L e n in, Teosed, 8. kd., Tallinn, 1952, lk. 219.

66 V. I. L e n i n, Teosed, 6. kd., Tallinn 1952, lk. 96-97.

67 V. I. L e n in, Teosed, 6. kd., Tallinn 1952, 1k, 370 ja $379 .-8$. kd., Tallinn 1952, lk. 206 . 
Rakendame Lenini poolt ta töös ,Sotsiaaldemokraatia agraarprogramm 1905.-1907. aastal toimunud esimeses vene revolutsioonis" sooritatud arvutuste skeemi ${ }^{68}$ maavaldusele Eestimaa kubermangus 1900. aastal. Alltoodud tabelis on näidatud maavalduse tegelik seis 1900 . aastal ja milliseks oleks kujunenud olukord, kui mõisnike ja pastorite käest oleks maa ära võetud ja võrdsetes osades kõigi talupoegade - nii jōukate, vaesemate, kui ka hoopis maatute - vahel jagatud.

\begin{tabular}{|c|c|c|c|c|c|c|}
\hline & \multicolumn{3}{|c|}{ Maaomandi tegelik seis 1900 . a. } & \multicolumn{3}{|c|}{$\begin{array}{l}\text { Maaomandi võimalik seis părast } \\
\text { revolutsiooni võitu }\end{array}$} \\
\hline & \multirow[b]{2}{*}{$\begin{array}{c}\text { majapida- } \\
\text { miste } \\
\text { arv }\end{array}$} & \multicolumn{2}{|c|}{ maaomand (tiinudes) } & \multirow[b]{2}{*}{$\begin{array}{c}\text { majapida- } \\
\text { miste } \\
\text { arv }\end{array}$} & \multicolumn{2}{|c|}{ maaomand (tiinudes) } \\
\hline & & kokku & $\begin{array}{c}\text { keskmiselt } \\
\text { ühe maja- } \\
\text { pidamise } \\
\text { kohta }\end{array}$ & & kokku & $\begin{array}{l}\text { the } \\
\text { majapid. } \\
\text { kohta }\end{array}$ \\
\hline Maatamehed & 44641 & - & - & - & - & - \\
\hline Renditalud & 13134 & $\rightarrow$ & - & - & - & - \\
\hline $\begin{array}{l}\text { Alla 1-tiinulised } \\
\text { talud }\end{array}$ & 55 & 29 & 0,5 & - & - & - \\
\hline $\begin{array}{l}1-15 \text {-tiinulised } \\
\text { talud }\end{array}$ & 1460 & 12792 & 9 & - & - & - \\
\hline $\begin{array}{l}15-60 \text {-tiinulised } \\
\text { talud }\end{array}$ & 7968 & 281275 & 35 & 66306 & $\approx 1127000$ & $19-79$ \\
\hline $\begin{array}{l}\text { Ole } 60 \text {-tiinulised } \\
\text { talud }\end{array}$ & 962 & 73494 & 76 & 1914 & $\approx 147500$ & $\begin{array}{c}74-92 \\
\text { (keskm. } 80 \text { ) }\end{array}$ \\
\hline Mõisad & 545 & 1314859 & 2413 & - & - & - \\
\hline Pastoraadid & 50 & 6664 & 133 & - & - & - \\
\hline
\end{tabular}

Nagu näeme, oleks Eesti kubermangus ka XX sajandi algul mõisamaade jagamise tagajärjel võitnud eranditult kõik talurahvakihid. Võrdlemisi väheoluline oleks see võit olnud ainult umbes tuhandele suurtaluomanikule, kuna aga kesktalupoegade maaomandi suurus oleks peaaegu kahekordistunud ${ }^{69}$. Sellise poliitökonoomilise analüüsiga tõestas Lenin vene sisekubermangude suhtes, et ka külakodanlus tõuseb võitlusesse mõisnike vastu, et ka tema on võimeline „saama demokraadiks" 70 .

Nagu näeme, oli eesti külakodanlus veel XX sajandi alguses majanduslikult huvitatud mõisnike võimu kukutamisest, mõisalatifundiumide jagamisest. Veelgi enam pidi ta aga seda olema XIX sajandi keskpaiku, kui talude päriseksost oli alles alanud, kui peaaegu kogu põllumajanduslikult haritav maa oli veel mõisnike omanduses. Et talurahvas neis tingimustes astus mõisnike vastu välja veel ühtse klassina, seda kinnitab toodud materjal. Ohtlasi näitavad toodud andmed ka seda, et mingist külakodanluse domineerivast või juhtivast osast tolleaegseis antifeodaalseis liikumistes ei ole alust rääkida.

68 Vt. V. I. L e n i n, Teosed, 13. kd., Tallinn 1953, lk, 202.

69 Tabel on koostatud järgmiste materjalide põhjal: E. v. B o d i s c o, Der BauerlandVerkauf in Estland und Materialien zur Agrar-Statistik Estlands, Reval 1902, 1k. 66, 97; lisa, lk, 46. - Первая всеобщая перепись населения Российской империи, 1897 г., под редакцией Н. А. Тройницкого, XLIX - Эстляндская губерния, СПб, 1905, Ik. 2-3.

70 V. 1. L e n i n, Teosed, 8. kd., Tallinn 1952, lk. 207. 
Mõisnikevastases võitluses esineval klassiühtsusel pole aga midagi ühist omal ajal kodanlike poliitikameeste ja ajaloolaste poolt välja mōeldud „,rahvusühtsusega". Needsamad talupojad, kes täna kirjutasid ühiselt alla mõisnikevastasele petitsioonile, võisid homme üksteist kohtusse kaevata võla maksmata jätmise, liigse tööga kurnamise või sihiliku näljutamise pärast, nagu me seda nägime eelmises artiklis.

Eesti NSV Teaduste Akadeemia Ajaloo Instituut
Saabus toimetusse

3. VIII 1955

\title{
О РОЛИ ДВОРОХОЗЯЕВ И БАТРАКОВ В АНТИФЕОДАЛЬНЫХ ВЫСТУПЛЕНИЯХ КРЕСТЬЯНСТВА ЭСТОНИИ В СЕРЕДИНЕ XIX BEKA
}

\author{
Ю. Ю. КАХҚ, \\ кандидат исторических наук
}

Резюме

- Вопрос о роли различных прослоек крестьянства в антифеодальных выступлениях XVIII-XIX вв. решается советскими историками по-разному. Одни считают, что уже в конце XVIII века и первой половине XIX века богатые крестьяне, возникающая сельская буржуазия, держат сторону помещиков; другие считают, что в указанный период крестьянство выступает против помещиков еще как единое целое.

40-60-е годы XIX века знаменуют в Эстонии утверждение капиталистической формации. Вместе с процессом становления буржуазного общества происходит расслоение эстонского крестьянства на сельский пролетариат и сельскую буржуазию; но поскольку в Эстонии, как и в остальных районах России, сохранились еще очень сильные пережитки крепостнических отношений, постольку крестьянство продолжало еще оставаться классом-сословием; все крестьянство как класс являлось врагом крепостнических порядков '

Для решения поставленной в настоящей статье задачи автором были подвергнуты анализу материалы крестьянского движения, развернувшегося в Эстляндской губернии в 1858 году, и кампании по представлению царю коллективных жалоб, имевшей место в южной Эстонии в 1860 1868 годах.

Основным требованием крестьян в 1858 году была отмена ненавистной крепостнической барщины. Более точные данные об отказе крестьян от выполнения барщинных повинностей имеются в отношении 15 имений, из них в 11 имениях выступали главным образом дворохозяева, в 4 имениях активно выступали и батраки. Летом того же года в 13 имениях сопротивление управляющим имениями при выполнении барщины оказали преимущественно батраки. О сопротивлении местным судебным властям имеются более точные данные в отношении 9 имений, причем в четырех случаях активно выступали главным образом дворохозяева, в двух случаях - батраки и в трех случаях имели место совместные выступления дворохозяев и батраков. По имеющимся данным, в выступлениях против местных властей, которые произошли несмотря на наличие на месте карательных отрядов, в пяти случаях более активно выступали дворохозяева, в двух случаях - батраки. При анализе указанных выше

1 См. В. И. Л ен ин, Соч. т. 6 , стр. 97. 
форм сопротивления надо иметь в виду, что отвечали перед помещиком и местными властями за отбывание повинностей и за «порядок» дворохозяева, с которыми в основном велись и переговоры во время выступлений крестьян. Поэтому в сохранившихся документах деятельность батрачества отображена значительно слабее, чем деятельность дворохозяев.

В связи с восстанием крестьян в имении Махтра местными властями были арестованы 30 дворохозяев, трое сыновей дворохозяев, 30 батраков, 2 корчмаря и один подросток. В ходе происшедшего в Махтра столкновения с войсками были убиты или ранены 10 дворохозяев, 10 батраков и 3 бобыля.

В отношении 12 имений удалось выяснить, что среди активных участников сопротивления были дворохозяева, которые уже через 20-30 лет сумели выкупить свои хутора. Из них 83 процента арендовали (а впоследствии приобрели в собственность) хутора с площадью более 30 десятин. Этих крестьян можно считать представителями возникающей сельской буржуазии.

На основе приведенных данных по крестьянскому движению 1858 года можно заключить, что в 1858 году в северной Эстонии крестьянство выступало против помещиков еще как единое целое. Ничто не говорит также о том, чтобы возникающей сельской буржуазии принадлежала при этом какая-либо руководящая роль, но она выступает против помешиков вместе с остальным крестьянством.

В своих наивных обращениях к царю крестьяне южной Эстонии выступили в 1860 годах с требованием дать им землю по «сходной» цене, отменить крепостническую барщину, провести демократическое преобразование местных органов власти и судопроизводства. В 1865 году во многих волостях прошения составлялись отдельно дворохозяевами и батраками-бобылями (безземельными). Содержание этих прошений показывает, что обе стороны взаимно учитывали интересы друг друга. Дворохозяева, требуя возвращения отнятых помещиком земель, подчеркивали, что эти земли нужно будет раздать безземельным. Со своей стороны, безземельные крестьяне поддерживали требования дворохозяев.

Одним из главных центров петицнонной кампании было казенное имение Хольстре, а главными руководителями ее были братья Петерсоны. В 1866 году местной крестьянской общине удалось получить это имение в аренду. Избранное крестьянами правление имения в скором времени роздало часть земель имения 45 безземельным крестьянам. Самым влиятельным членом правления был признанный руководитель всей «кампании» Адам Петерсон. Он был избран в состав правления в 1866 году главным образом голосами батраков и бобылей.

В большинстве прошений крестьяне высказывались против принудительного выкупа земли по высоким ценам. Удалось выяснить, что в трех волостях, где были составлены прошения, направленные против принудительного выкупа земли, среди просителей были и дворохозяева, приступившие уже в ближайшие годы к выкупу своих хуторов. Под «великим прошением 1864 года» в волости Хольстре подписались и два крестьянина, о которых известно, что они занимались ростовщичеством.

Все эти данные говорят о том, что и в петиционной кампании в 1860 1868 годы крестьянство выступало еще как единөе целое. К такому же выводу приходили уже раньше и другие исследователи в отношении крестьянского движения 1840 -х годов в южной Эстонии и крестьянского движения 1880-х годов в северо-западной Эстонии. 
$\mathrm{B}$ предыдущей статье автора ${ }^{2}$ говорилось о той группе сельской буржуазии (корчмари, мельники, арендаторы мыз и др.), которая стала возникать уже с конца XVIII века. Для нее характерно тесное сотрудничество с помещиками. В отличие от этой группы, та часть сельской буржуазии, которая стала расти начиная с 1840 -х годов, выступала против помещиков совместно с другими крестьянами.

На основе тщательного изучения опыта революции 1905-1907 годов Ленин показал, что крестьянство в то время выступало против помещиков еще как единый класс и что вместе с другими крестьянами шла и возникающая сельская буржуазия. Ленинская характеристика роли крестьянства в революции 1905-1907 годов применима к антифеодальным выступлениям эстонских крестьян в середине XIX столетия.

Однако эстонское крестьянство было едино только в своих выступлениях против помещика; во всех остальных вопросах, как мы видели в предыдущей статье, усиливался антагонизм между двумя полюсами расслаивающегося крестьянства.

Ннститут истории

Академии наук Эстонской ССР
Поступила в редакцию 3 VIII 1955

2 Ю. Ю. К а хк, О возникновении сельской буржуазии и сельского пролетариата в Эстонской деревне, Известия АН ЭССР, т. IV, № 3, 1955. 